\title{
Høytflygende hjelp
}

\author{
I Tidsskriftet nr. 22/1934 redegjør det nyopprettede Widerøe's flyveselskap for sin plan for organiseringen \\ av en luftambulansetjeneste i Norge. Det skulle stasjoneres tre fly i sør og ett i nord - i Oslo, Bergen, \\ Trondheim og Harstad. For å kartlegge behovet og beregne det økonomiske grunnlaget for en slik tjeneste \\ bes legene fylle ut et skjema. Slik kan man komme på høyde med svenskene, som da allerede hadde hatt \\ flyambulansestasjoner i ti år (Tidsskr Nor Lægeforen 1934; 54: 1205-10).
}

\section{Ambulanseflyvning.}

\section{Til den norske lægestand fra Widerøe's flyveselskap A/S.}

Da vårt selskap ble dannet $\mathrm{i}$ begynnelsen av året, søkte vi samarbeid med Røde Kors for eventuelt å organisere ambulanseflyvning på Østlandet og i fjelldistriktene. I den anledning blev våre 2 Wacofly - begge moderne, innelukkede 4-seter fly - utstyrt med syketransport for øie, og det er også i løpet av vinteren og sommerhalvåret blitt utført en rekke ambulanseflyvninger fra høifjellet.

Årets syketransporter pr. fly blev alle programmessig gjennemført, og de forhåpninger vi stilte til dette transportmiddel, blev innfridd fullt ut. Vi har derfor besluttet oss for å ta denne sak op påny, og denne gang med det mål for øie å organisere et greit og effektivt ambulansesystem for hele landet.

Det avhenger jo ofte av den tid som går hen fra sykdomseller ulykkestilfellet inntreffer, til hjelp kan skaffes, om menneskeliv kan reddes eller ikke. I mange tilfeller er det timer det kommer an på, og over store avstander i kommunikasjonsfattige strøk gir derfor flyet den beste løsning når talen er om et effektivt og hurtig transportmiddel til nærmeste sykehus, enten det gjelder akutte sykdommer eller farlige ulykkestilfelle. Likeledes forkorter en hurtig transport lidelsene for den syke, selv om det ikke i alle tilfelle gjelder liv og død. (...)

Til syketransport skal benyttes et 4-seter Waco cabin sjøfly, lydisolert og opvarmet, med innmontert sykebåre, som lett kan tas ut og anvendes for andre transportmidler. Flyene har en reisefart på $200 \mathrm{~km}$./time, hvorved de lengste transporter ikke skulde vare lenger end $11 / 2$ time, og den tid som medgår fra bestilling av ambulansefly til den syke er i sykehus, skulde ikke i noget tilfelle overstige $31 \frac{1}{2}$ time.

Man kan gjøre regning med at flyene kan lande og opta syke på ethvert sted hvor det finnes åpent vann på ca. $1 \mathrm{~km}$. $i$ alle retninger.

Det er meningen at ambulansestasjonene skal oprettes og drives i forbindelse med de kommende luftruter, idet ambulanseflyene samtidig skal ligge som reservefly for rutene og benyttes til mindre leilighetsturer. Harstadflyet tenkes dessuten anvendt $\mathrm{i}$ tråleropsynets tjeneste. Kun gjennem felles administrasjon og allsidig utnyttelse av flyene kan utgiftene til driften bli så små at en ambulansetjeneste for hele landet kan gjennemføres.
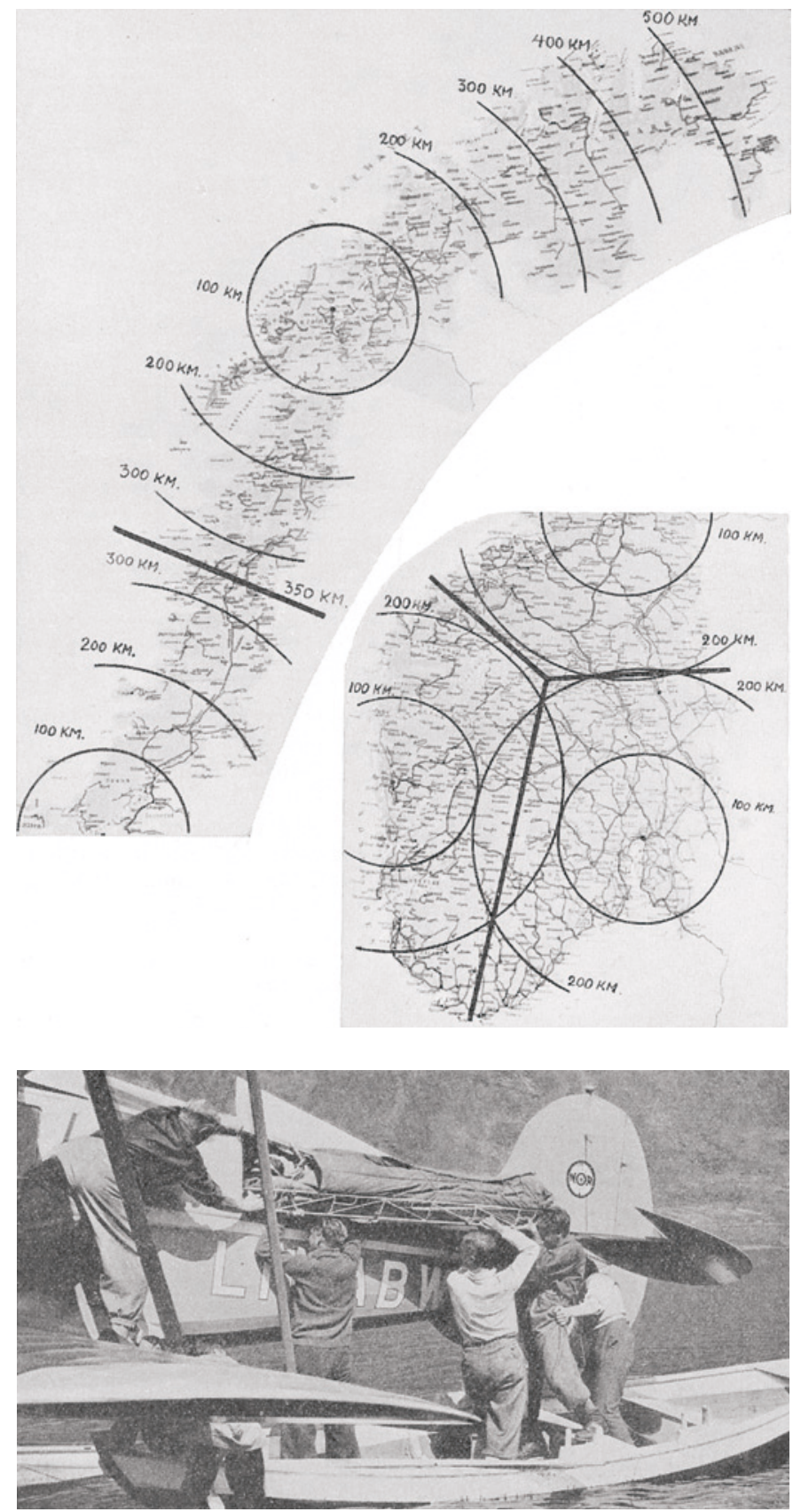